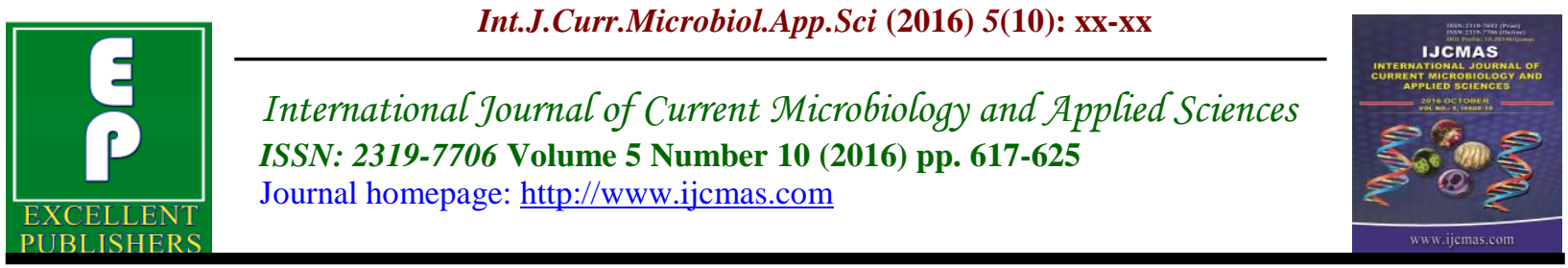

Original Research Article

http://dx.doi.org/10.20546/ijcmas.2016.510.069

\title{
Antimicrobial and Phytochemical Analysis of Methanolic and Aqueous Extract of Annona muricata (Leaf and Fruit)
}

\author{
R. Vinothini* and Lali Growther \\ Department of Microbiology, Hindusthan College of Arts \& Science, \\ Coimbatore-6410 28, India \\ *Corresponding author
}

Keywords

Annona muricata, Anti fungal, Anti bacterial, Phytochemical.

\section{Article Info}

Accepted:

20 September 2016 Available Online: 10 October 2016
A B S T R A C T

Annona muricata is a species of the genus Annona of the custard apple tree family, Annonaceae, which has edible fruit. The aim of this study was to carryout for check the Antibacterial, Antifungal and Phytochemical activity from methanolic and aqueous extract of leaf and fruit of Annona muricata. An antibacterial activity of Annona muricata was evaluated on Pathogenic bacteria (Staphylococcus aureus, Streptococcus pyogenes, Pseudomonas aeruginosa, Salmonella typhi, Klebsiella pneumoniae, Escherichia coli and Proteus mirabilis) by Well diffusion method. Antifungal activity of Annona muricata was evaluated on Cryptococcus neoformans and Candida albicans. Phytochemical analysis was done by using standard methods. Phytochemical screening was used to determine the presence of Alkaloids, Flavonoids, Carbohydrates, Glycosides, Proteins, Amino acids, Saponins, Tannins, Terpenoids in Methanolic and Aqueous extract of Annona muricata. These findings support the traditional use of Annona muricata in varies disorders.

\section{Introduction}

Plants are one of the most important sources of medicines for treating illnesses since the beginning of human civilization (Jyothi et al., 2011). In recent times, and due to historical, cultural, and other reasons, folk medicine has taken an important place, especially in developing countries, where health services are limited. The study on the medicinal plants is essential to promote the proper use of herbal medicine in order to determine their potential as a source for the new drugs (Gajalakshmi et al., 2012).
Ayurvedic medicine uses all of these either in diet or as a medicine. Some of these medicinal plants like Tulsi (Ocimum sanctum), Haridra (Curcuma longa), sarpagandha (Rauvolfia serpentia) and Ghritkumari (Aleo barbadensis) have been featured on Indian postage stamps. Among this one of the important medicinal plants which show many medicinal properties is Annona muricata (In Tamil, Mullu seetha). Annona muricata is a member of the family of custard apple tree called Annonaceae and 
species of the genus Annona known mostly for its edible fruit Annona. It is a small upright evergreen tree 5-6 meter height with large, glossy, dark green leaves. It produce a large heart shaped, edible fruit, $5-20 \mathrm{~cm}$ in diameter, yellow green in colour and has white flesh inside. Annona muricata produce fruit that are usually called soursop due to its slightly acidic taste when ripe (Hutchinson et al., 2011). The fruit is juicy, acidic, whitish and aromatic with abundant seeds. The average weight of 1000 fresh seeds is $479 \mathrm{~g}$ and has an average oil content of $24 \%$ (Hutchings, 2006). The creamy and delectable flesh of fresh fruit consists of $80 \%$ of water, $1 \%$ protein, $18 \%$ carbohydrate and fair amount of Vitamin B, $\mathrm{B} 2$ and $\mathrm{C}$ and Potassium and dietary fiber. Annonaceous acetogeneins are powerful phytochemicals found in the Graviola plant (Annona muricata), which are found only in Annonaceae family. These chemicals in general have been documented with Antitumor, Antiparasitic, Insecticidal and Anti-microbial activities. These acetogeneins are superb inhibitors of enzyme processes that are found only in the membranes of cancerous tumour cells.

The leaves and stems of soursop show active cytotoxicity against cancer cells, due to bioactive compounds called acetogenins. These acetogenins are non-toxic to normal cells, but are highly toxic to cancer cells (Oberlies et al., 1995). Acetogenins from the soursop plant are usually extracted using ethanol as the organic solvent (Zeng et al., 1996). These compounds, collectively, have shown antitumor, parasiticidal, pesticidal, and antimicrobial activities (McLaughlin, 2008). The cytotoxicity of annonaceous acetogenins is due to the depletion of ATP levels via the inhibition of the NADPubiquinone oxidoreductase (Complex I) of the mitochondrial electron transport system (Zafra-Polo et al., 1996). The lactone ring present in acetogenin molecules plays an important role in the anticancer mechanism, present (Kreuger et al., 2012). Annonacin is known as the most prevalent acetogenin present in soursop leaves (Champy et al., 2004; Yuan et al., 2003), however, the method for separation of annonacin from soursop leaves is not widely reported. More reports are available on various methods to obtain new acetogenins from soursop leaves (Kim et al., 1998; Zeng et al., 1996).

The objective of this research work is to check the antimicrobial activity of Annona muricata against pathogenic organisms like Staphylococcus aureus, Streptococcus pyogenes, Escherichia coli, Pseudomonas aeruginosa, Proteus mirabilis, Klepsiella pneumonia and Salmonella typhi. Antifungal activity was checked against Candida albicans and Cryptococcus neoformans. And to screen the aqueous and methanolic extract of Annona muricata for their biologically active chemicals, with a view to provide a scientific basis for use of the leaves for prevention and treatment of diseases.

\section{Materials and Methods}

\section{Sample collection and authentication}

A.muricata L. Leaves and fresh ripe fruits (5 $\mathrm{kg}$ ) were collected locally at Gudalur, Ooty in the month of July 2016. Leaves and fruits were authenticated (BSI/SRC/5/23/ $2016 /$ Tech/1223) by the authority of the botanical survey of India (BSI), Tamil Nadu Agricultural University, Coimbatore.

\section{Sample preparation}

A.muricata leaves were washed thoroughly under running tap water, air dried and homogenized to fine powder and stored in sterile air tight container for the 
experimental work. A.muricata fruits were washed in tap water Seeds and pericarps were carefully removed and pulp was lyophilized for further use.

\section{Preparation of Methanolic and Aqueous extracts}

Air dried powder of leaves and lyophilized fruit pulp was extracted by using Soxhlet apparatus. $10 \mathrm{~g}$ of A.muricata leaf and fruit powder was taken in a paper cone and placed into soxhlet apparatus. $100 \mathrm{ml}$ of solvent (methanol and water) was taken in the round bottom flask attached to this setup. Then the whole setup was placed on the heating mantle. The temperature was setup to $65-80^{\circ} \mathrm{C}$ solvents get vaporized and rises up to the condenses back in to the liquid and falls in to the plant sample in the cone and extract certain compounds falls in to the round bottom flask.

Methanol extract of leaf (dark green color) and fruit (yellowish brown) was evaporated to dryness at low temperature, by using rotary evaporator. And aqueous extract of leaf (brown color) and fruit (light brown) was evaporated by hot plate method (Satyanarayana, 2006). Concentrated extracts were dissolved in DMSO for antimicrobial studies.

\section{Microbial cultures}

Microorganisms Staphylococcus aureus, Streptococcus pyogenes, Pseudomonas aeruginosa, Salmonella typhi, Klebsiella pneumoniae, Escherichia coli, Proteus mirabilis, Cryptococcus neoformans and Candida albicans were obtained from KMCH Hospital, Coimbatore, Tamilnadu. And the cultures were further conformed by staining and biochemical methods. Antimicrobial activity was examined for aqueous and methanol extract from the fruit and leaves of Annona muricata.

\section{Antimicrobial activity by well diffusion method}

Molten Mueller Hinton agar was prepared and poured into petri dishes and the bacterial culture was swabbed on the surface of agar to check the antibacterial activity. And a well was made by using $6 \mathrm{~mm}$ well cutter. Aqueous and methanolic extracts of fruit and leaves of Annona muricata was added into well in the concentration of $50 \mu 1,100 \mu 1$ and $200 \mu \mathrm{l}$ respectively. For each bacterial strain positive and negative controls were maintained. Antibacterial activity of the extract was determined by measuring the diameter of zone of inhibition.

To check the antifungal activity Sabouraud dextrose agar was prepared and poured into petri dishes and the fungal culture was swabbed on the surface of agar. A well was made by using $6 \mathrm{~mm}$ well cutter.

Aqueous and methanolic extracts of fruit and leaves of Annona muricata was added into well in the concentration of $50 \mu 1,100 \mu 1$ and $200 \mu \mathrm{l}$ respectively. For each fungal culture positive and negative controls were maintained. Antifungal activity of the extract was determined by measuring the diameter of zone of inhibition.

\section{Phytochemical screening}

Phytochemical examinations were carried out for all the extracts as per the standard methods. (Roopashree et al., 2008; Obasi et al., 2010).

\section{Results and Discussion}

\section{Antibacterial activity}

Antibacterial activity for ethanolic and aqueous extract of Annona muricata was seen against to the several organisms namely 
Staphylococcus aureus, Streptococcus pyogenes, Pseudomonas aeruginosa, Salmonella typhi, Klebsiella pneumoniae, Escherichia coli and Proteus mirabilis.

The methanol and aqueous leaf extract showed maximum activity against Streptococcus pyogenes. And the methanol and aqueous fruit extract showed maximum activity against Staphylococcus aureus and Salmonella typhi as shown in table 1 and 2.

\section{Antifungal activity}

Antifungal activity for ethanolic and aqueous extract of Annona muricata was seen against Candida albicans and Cryptococcus neoformans. The methanol and aqueous leaf extract showed maximum activity against Cryptococcus neoformans. And the methanol and aqueous fruit extract showed maximum activity against Candida albicans as shown in Table 3 and 4.

Table.1 Antibacterial activity for methanolic and aqueous leaf extract of Annona muricata

\begin{tabular}{|c|c|c|c|c|c|c|c|c|}
\hline \multirow[t]{3}{*}{ Test organisms } & \multicolumn{3}{|c|}{$\begin{array}{c}\text { Concentration of } \\
\text { methanol } \\
\text { extract }(\mu \mathrm{l})\end{array}$} & \multicolumn{3}{|c|}{$\begin{array}{c}\text { Concentration of } \\
\text { aqueous extract }(\mu \mathrm{l})\end{array}$} & \multirow[t]{2}{*}{$\begin{array}{c}\text { Positive control } \\
\text { (Streptomycin } \\
0.1 \mathrm{mg} / \mathrm{ml} \text { ) }\end{array}$} & \multirow[t]{2}{*}{$\begin{array}{l}\text { Negative } \\
\text { control } \\
\text { (DMSO) }\end{array}$} \\
\hline & 50 & 100 & 200 & 50 & 10( & 200 & & \\
\hline & \multicolumn{6}{|c|}{ Diameter of inhibition (mm) } & \multicolumn{2}{|c|}{ Diameter of inhibition(mm) } \\
\hline Staphylococcus aureus & 14 & 20 & 22 & 10 & 12 & 15 & 18 & - \\
\hline Streptococcus pyogenes & 18 & 20 & 24 & 11 & 14 & 18 & 20 & - \\
\hline Pseudomonas aeruginosa & 15 & 21 & 22 & 10 & 13 & 16 & 17 & - \\
\hline Klebsiella pneumonia & 14 & 22 & 23 & 13 & 15 & 18 & 20 & - \\
\hline Proteus mirabilis & 13 & 19 & 21 & - & - & 13 & 15 & - \\
\hline Escherichia coli & 20 & 22 & 24 & 10 & 13 & 15 & 20 & - \\
\hline Salmonella typhi & 18 & 20 & 22 & 15 & 18 & 20 & 20 & - \\
\hline
\end{tabular}

Table.2 Antibacterial activity for methanolic and aqueous fruit extract of Annona muricata

\begin{tabular}{|c|c|c|c|c|c|c|c|c|}
\hline \multirow[t]{3}{*}{ Test organisms } & \multicolumn{3}{|c|}{$\begin{array}{c}\text { Concentration of } \\
\text { methanol } \\
\operatorname{extract}(\mu \mathrm{l})\end{array}$} & \multicolumn{3}{|c|}{$\begin{array}{c}\text { Concentration of } \\
\text { aqueous extract }(\mu \mathrm{l})\end{array}$} & \multirow[t]{2}{*}{$\begin{array}{l}\text { Positive control } \\
\text { (Streptomycin } \\
\text { 0.1mg/ml) }\end{array}$} & \multirow[t]{2}{*}{$\begin{array}{c}\text { Negative } \\
\text { control } \\
\text { (DMSO) }\end{array}$} \\
\hline & 50 & 100 & 200 & 50 & 100 & 200 & & \\
\hline & \multicolumn{6}{|c|}{ Diameter of inhibition (mm) } & \multicolumn{2}{|c|}{ Diameter of inhibition(mm) } \\
\hline Staphylococcus aureus & 13 & 18 & 24 & 18 & 20 & 22 & 18 & - \\
\hline Streptococcus pyogenes & - & 15 & 20 & - & 11 & 17 & 20 & - \\
\hline Pseudomonas aeruginosa & 11 & 15 & 18 & - & 13 & 18 & 17 & - \\
\hline Klebsiella pneumonia & - & 18 & 22 & - & - & 14 & 20 & - \\
\hline Proteus mirabilis & - & - & 18 & - & - & 15 & 15 & - \\
\hline Escherichia coli & - & 18 & 22 & - & - & 14 & 20 & - \\
\hline Salmonella typhi & 18 & 22 & 28 & 15 & 18 & 26 & 20 & - \\
\hline
\end{tabular}


Table.3 Antifungal activity for methanolic and aqueous leaf extract of Annona muricata

\begin{tabular}{|c|c|c|c|c|c|c|c|c|}
\hline \multirow[t]{3}{*}{ Test organisms } & \multicolumn{3}{|c|}{$\begin{array}{c}\text { Concentration of } \\
\text { methanol } \\
\operatorname{extract}(\mu \mathrm{l})\end{array}$} & \multicolumn{3}{|c|}{$\begin{array}{c}\text { Concentration of } \\
\text { aqueous extract }(\mu \mathrm{l})\end{array}$} & \multirow[t]{2}{*}{$\begin{array}{c}\text { Positive control } \\
\text { (Amphotericin B } \\
0.1 \mathrm{mg} / \mathrm{ml} \text { ) }\end{array}$} & \multirow[t]{2}{*}{$\begin{array}{c}\text { Negative } \\
\text { control } \\
\text { (DMSO) }\end{array}$} \\
\hline & 50 & 100 & 200 & 50 & 100 & 200 & & \\
\hline & \multicolumn{6}{|c|}{ Diameter of inhibition (mm) } & \multicolumn{2}{|c|}{ Diameter of inhibition(mm) } \\
\hline Candida albicans & - & 14 & 16 & 14 & 16 & 18 & 20 & - \\
\hline Cryptococcus neoformans & 18 & 20 & 24 & 17 & 19 & 21 & 18 & - \\
\hline
\end{tabular}

Table.4 Antifungal activity for methanolic and aqueous fruit extract of Annona muricata

\begin{tabular}{|c|c|c|c|c|c|c|c|c|}
\hline \multirow[t]{3}{*}{ Test organisms } & \multicolumn{3}{|c|}{$\begin{array}{c}\text { Concentration of } \\
\text { methanol } \\
\text { extract }(\mu \mathrm{l})\end{array}$} & \multicolumn{3}{|c|}{$\begin{array}{c}\text { Concentration of } \\
\text { aqueous extract }(\mu \mathrm{l})\end{array}$} & \multirow[t]{2}{*}{$\begin{array}{c}\text { Positive control } \\
\text { (Amphotericin B } \\
0.1 \mathrm{mg} / \mathrm{ml} \text { ) }\end{array}$} & \multirow[t]{2}{*}{$\begin{array}{c}\text { Negative } \\
\text { control } \\
\text { (DMSO) }\end{array}$} \\
\hline & 50 & 100 & 200 & 50 & 100 & 200 & & \\
\hline & \multicolumn{6}{|c|}{ Diameter of inhibition (mm) } & \multicolumn{2}{|c|}{ Diameter of inhibition(mm) } \\
\hline Candida albicans & 18 & 20 & 23 & 18 & 20 & 22 & 18 & - \\
\hline Cryptococcus neoformans & 18 & 20 & 22 & 15 & 17 & 18 & 20 & - \\
\hline
\end{tabular}

Fig.1 Antibacterial activity for Aqueous extract of Annona muricata

$\mathbf{A}$ B C

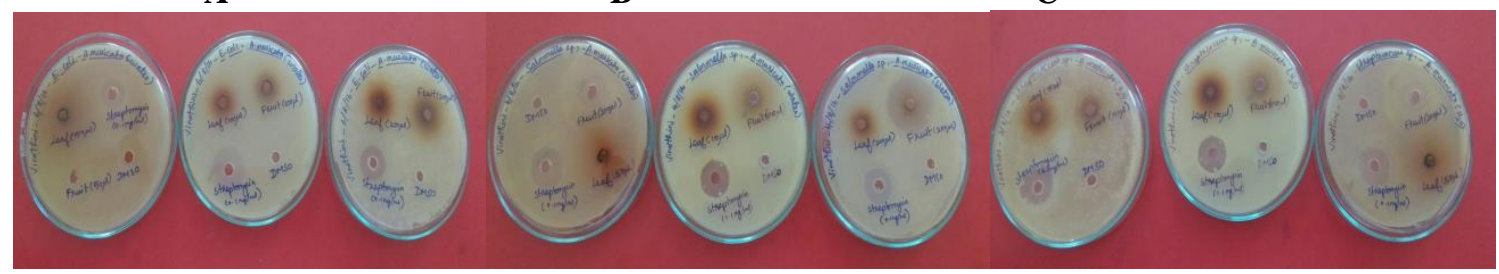

D

$\mathbf{E}$

$\mathbf{F}$

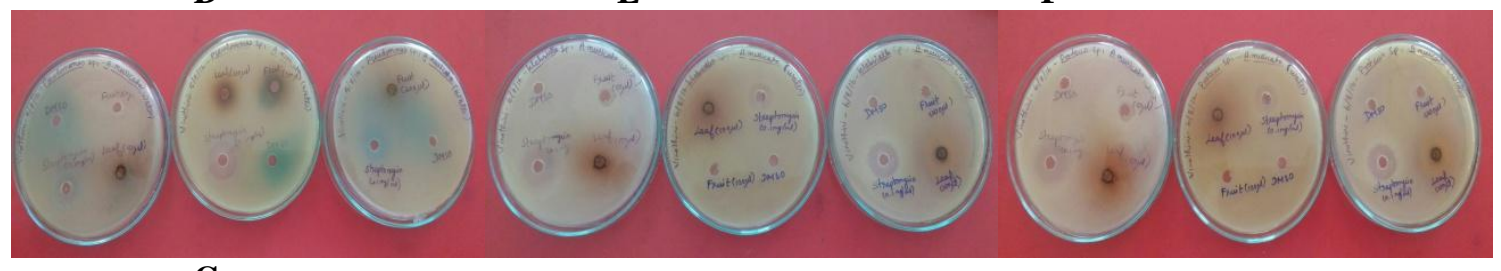

G

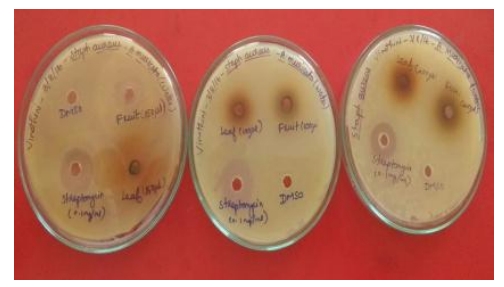

$\begin{array}{lll}\text { A) Escherichia coli } & \text { B)Salmonella typhi } & \text { C)Streptococcus pyogenes }\end{array}$

D)Pseudomonas aeruginosa E)Klebsiella pneumonia

F)Proteus mirabilis $\mathbf{G ) S t a p h y l o c o c c u s ~ a u r e u s ~}$ 
Table.5 Qualitative phytochemical screening of aqueous and methanol extract of Annona muricata

\begin{tabular}{|c|c|c|c|c|c|}
\hline \multirow[t]{2}{*}{ S.No } & \multirow[t]{2}{*}{ Test } & \multicolumn{2}{|c|}{ Aqueous extract } & \multicolumn{2}{|c|}{ Methanol extract } \\
\hline & & Leaf & Fruit & Leaf & Fruit \\
\hline 1. & $\begin{array}{l}\text { Test for alkaloids } \\
\text { a)Mayer's test } \\
\text { b)Wagner's test } \\
\text { c)Hager's test }\end{array}$ & $\begin{array}{l}+ \\
+ \\
+\end{array}$ & $\begin{array}{l}+ \\
- \\
+\end{array}$ & $\begin{array}{l}+ \\
+ \\
+\end{array}$ & $\begin{array}{l}+ \\
- \\
+\end{array}$ \\
\hline 2. & $\begin{array}{l}\text { Test for flavonoids } \\
\text { a)Alkaline reagent } \\
\text { test } \\
\text { b)Lead acetate test }\end{array}$ & $\begin{array}{l}+ \\
+\end{array}$ & $\begin{array}{l}+ \\
-\end{array}$ & $\begin{array}{l}+ \\
+\end{array}$ & $\begin{array}{l}+ \\
+\end{array}$ \\
\hline 3. & $\begin{array}{l}\text { Test for carbohydrates } \\
\text { a)Benedict's test } \\
\text { b)Molisch's test } \\
\text { c)Fehling's Test }\end{array}$ & $\begin{array}{l}+ \\
+ \\
+\end{array}$ & $\begin{array}{l}+ \\
+ \\
+\end{array}$ & $\begin{array}{l}+ \\
+ \\
+\end{array}$ & $\begin{array}{l}+ \\
+ \\
+\end{array}$ \\
\hline 4. & $\begin{array}{l}\text { Test for glycosides } \\
\text { a)Borntrager's test } \\
\text { b)Legal's test }\end{array}$ & $\begin{array}{l}+ \\
+\end{array}$ & $\begin{array}{l}+ \\
+\end{array}$ & $\begin{array}{l}+ \\
+\end{array}$ & $\begin{array}{l}+ \\
+\end{array}$ \\
\hline 5. & $\begin{array}{l}\text { Test for saponin } \\
\text { a)Froth test } \\
\text { b)Foam test }\end{array}$ & $\begin{array}{l}+ \\
+\end{array}$ & $\begin{array}{l}+ \\
+\end{array}$ & $\begin{array}{l}+ \\
+\end{array}$ & $\begin{array}{l}+ \\
+\end{array}$ \\
\hline 6. & $\begin{array}{l}\text { Test for phenols } \\
\text { a)Ferric chloride test }\end{array}$ & - & - & + & + \\
\hline 7. & $\begin{array}{l}\text { Test for tannins } \\
\text { a)Gelatin test }\end{array}$ & + & - & + & - \\
\hline 8. & $\begin{array}{l}\text { Test for protein and } \\
\text { amino acids } \\
\text { a)Xanthoproteic test } \\
\text { b)Ninhydrin test }\end{array}$ & $\begin{array}{l}+ \\
+\end{array}$ & $\begin{array}{l}+ \\
+\end{array}$ & $\begin{array}{l}+ \\
+\end{array}$ & $\begin{array}{l}+ \\
+\end{array}$ \\
\hline 9. & $\begin{array}{l}\text { Test for terpenoids } \\
\text { a)Salkowski test } \\
\text { b)Copper acetate test }\end{array}$ & $\begin{array}{l}+ \\
+\end{array}$ & $\begin{array}{l}- \\
+\end{array}$ & $\begin{array}{l}+ \\
+\end{array}$ & $\begin{array}{l}- \\
+\end{array}$ \\
\hline 10. & $\begin{array}{l}\text { Test for anthraquinone } \\
\text { a)Ammonia test }\end{array}$ & - & - & - & - \\
\hline
\end{tabular}


Fig.2 Antibacterial activity for methanol extract of Annona muricata

A B

C

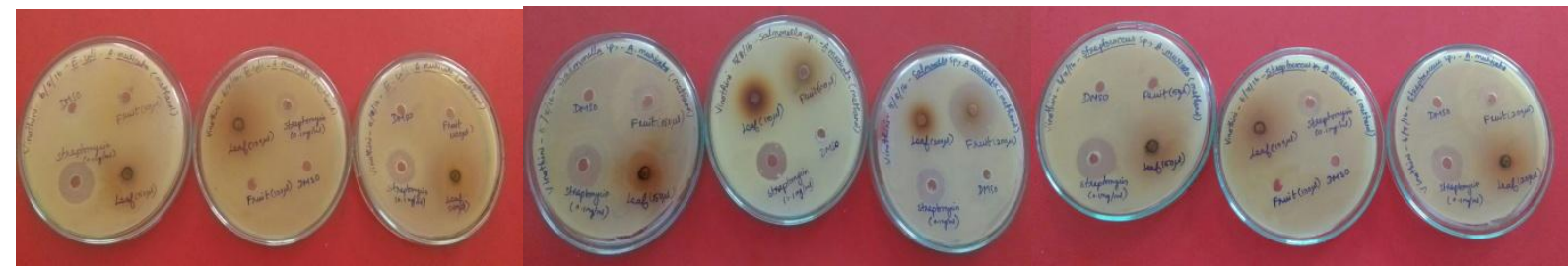

D

$\mathbf{E}$

F

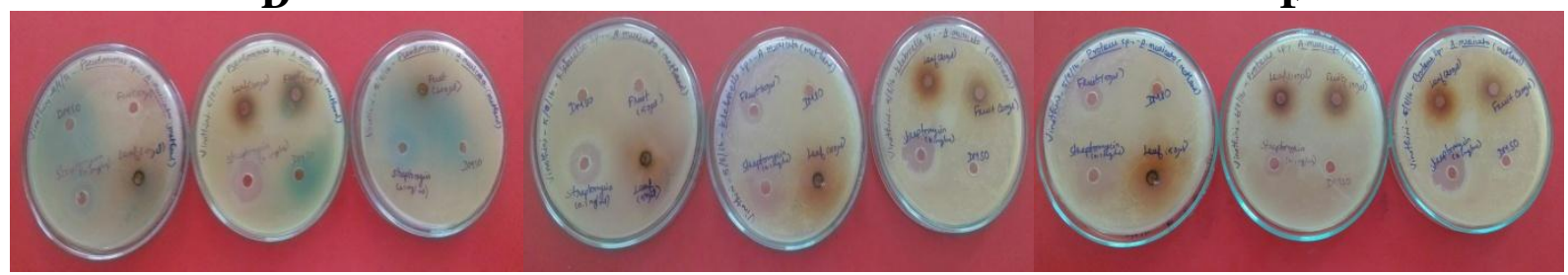

G

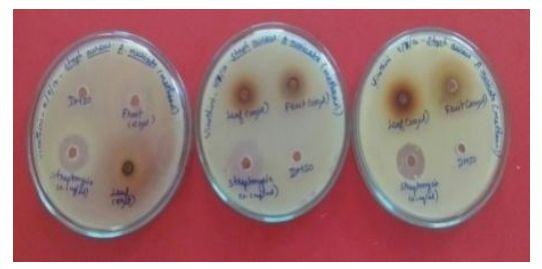

$\begin{array}{lll}\text { A)Escherichia coli } & \text { B)Salmonella typhi } & \text { C)Streptococcus pyogenes }\end{array}$

D)Pseudomonas aeruginosa E)Klebsiella pneumoniae

F)Proteus mirabilis

G)Staphylococcus aureus

Fig.3 Antifungal activity for methanol and aqueous extract of Annona muricata

A) Cryptococcus neoformans

B)Candida albicans

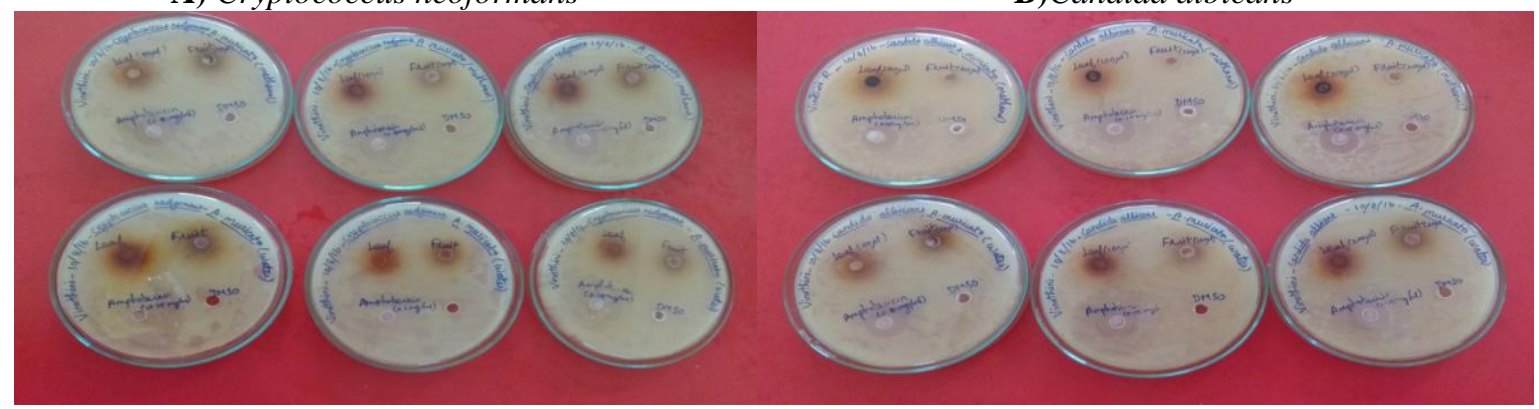

\section{Phytochemical screening}

The present study reveals that Annona muricata plant shows the presence of phytochemical constituents like alkaloids, carbohydrates, glycosides, proteins, aminoacids, saponins, tannins, terpenoids and anthraquinones in methanol and aqueous leaf and fruit extract of Annona muricata as shown in Table 5.
Antimicrobial activity of methanol and aqueous extract of Annona mricata (fruit and leaf) was determined by well diffusion method (Abubacker et al., 2012). Methanol extract of Annona muricata showed maximum antimicrobial activity than aqueous extract. Results of the phytochemical screening of Annona muricata methanolic leaf and fruit extract showed the absence of anthraquinone while 
flavonoids, saponins, tannins, phenols, alkaloids, terpenoids, protein, amino acids and glycosides were present. And Annona muricata aqueous leaf and fruit extract showed the absence of phenol and anthraquinone. (Roopashree et al., 2008; Obasi et al., 2010). These phytochemicals exhibit various pharmacological and biochemical actions when ingested by animals. The comparative antimicrobial activity between methanolic and aqueous extracts of Annona muricata and the standard antibiotic streptomycin and amphotericin B revealed that the methanolic extract showed significant antimicrobial efficacy and could compete with the standard antibiotic, streptomycin and amphotericin B. This study discovered that Annona muricata extract possess a broad spectrum of activity against a panel of microbial responsible for the most common bacterial and fungal diseases.

In conclusion, the present study demonstrates that Annona muricata has antibacterial and antifungal activity against various test organisms like Staphylococcus aureus, Streptococcus pyogenes, Pseudomonas aeruginosa, Salmonella typhi, Klebsiella pneumoniae, Escherichia coli, Proteus sp., lactobacillus sp., Cryptococcus neoformans and Candida albicans. And this study shows that Annona muricata is a good source for various phytochemicals like alkaloids, flavonoids, carbohydrates, glycosides, saponins, tannins, terpenoids, proteins and anthraquinone. All these preliminary reports form a primary platform for further phytochemical and pharmacological studies.

\section{Acknowledgement}

The authors are thankful to the Management, Hindusthan College of Arts and Science, for all the support and encouragement.

\section{References}

Abubacker, M.N. and Deepalakshmi, T. 2012. Antioxidant and antibacterial activity of Annona muricata L. leaf aqueous extract. Int. J. Plant Sci., 7: 301-306.

Champy, P., Hoglinger, G.U., Feger, J., Gleye, C., Hocquemiller, R., Laurens, A., Guerineau, V., Laprevote, O., Medja, F., Lombes, A., Michel, P.P., Lannuzel, A., Hirsch, E.C., Ruberg, M. 2004. Annonacin, a Lipophilic Inhibitor of Mitochondrial Complex I, Induces Nigral and Striatal Neurodegeneration in Rats: Possible Relevance for Atypical Parkinsonism in Guadeloupe. J. Neurochem., 69, Volume 88, pp. 63.

Gajalakshmi, S., Vijayalakshmi, S., Rajeswari, V. 2012. Phytochemical and pharmacological properties of Annona muricata: A review. Int. J. Pharm. Pharmaceu. Sci., 4(2): 3-6.

Hutchings, A. 2006. Zulu Medicinal Plants. An Inventory. University of Natal Press, Pietermaritzburg. $300-325$.

Hutchinson, J.D. and Dalziel, J.M. 2011. Flora of west tropical Africa, London, Vol. 1 Part 2: 450 - 5.

Jyothi, A., Venkatesh, K., Chakrapani, P., Roja, R. 2011. Phytochemical and pharmacological potential of Annona cherimola - A review. Int. J. Phytomed., 3: 439-47.

Kim, G.S., Zeng, L., Alali, F., Rogers, L.L., Wu, F.E., Sastrodihardjo, S., McLaughlin, J.L. 1998. Muricoreacin and Murihexocin C, Monotetrahydrofuran acetogenins, from the Leaves of Annona muricata. Phytochem., Volume 49(2), pp. 565571

Kreuger, M.R.O., Grootjans, S., Biavatti, M.W., Vandenabeele, P., Herde, K.D. 2012. Sesquiterpene Lactones as 
Drugs with Multiple Targets in Cancer Treatment: Focus on Parthenolide. Anticancer Drugs, Volume 23(9), pp. 883-896

McLaughlin, J.L. 2008. Paw Paw and Cancer: Annonaceous Acetogenins from Discovery to Commercial Products. J. Natural Product, Volume 71(7), pp. 1311-1321.

Obasi, N.L., Egbuonu, A.C.C., Ukoha, P.O., Ejikeme, P.M. 2010. Comparative phytochemical and antimicrobial screening of some solvent extracts of Samanea saman pods. African J. Pure and Appl. Chem., 4(9): 206-212.

Oberlies, N.H., Jones, J.L., Corbett, T.H., Fotopoulos, S.S., McLaughlin, J.L. 1995. Tumor Cell Growth Inhibition by Several Annonaceous Acetogenins in an in Vitro Disk Diffusion Assay. Cancer Letters, Volume 96(1), pp. 55-62

Roopashree, T.S., Dang, R., Rani, S.R.H., Narendra, C. 2008. Antibacterial activity of anti-psoriatic herbs: Cassia tora, Momordica charantia and Calendula officinalis. Int. J.
Appl. Res. Natural Products, 1(3): 20-28.

Satyanarayana, T. 2006. Hypoglycemic and antihyperglycemic effect of alcoholic extract of euphorbia leucophylla and its fractions in normal and in alloxan induced diabetic rats. Pharmacog Mag, 2: 244-53.

Yuan, S.S.F., Chang, H.L., Chen, H.W. Yeh, Y.T., Kao, Y.H., 2003. Annonacin, a Mono-tetrahydrofuran Acetogenin, Arrests Cancer Cells at the G1 Phase and Causes Cytotoxicity in a Baxand Caspase-3-related Pathway. Life Sci., Volume 72(25), pp. 2853-2861

Zafra-Polo, M.C., Gomzales, M.C., Estonell, E., Sahpaz, S., Cortes, D. 1996. Acetogenins from Annonaceae, Inhibitors of Mitochondrial Complex I. Phytochem., Volume 42(2), pp. 253-271.

Zeng, L., Ye, Q., Oberlies, N.H., Shi, G., Gu, Z.-M., He, K., McLaughlin, J.L. 1996. Recent Advances in Annonaceous Acetogenins. Natural Product Reports, Volume 13(4), pp. 275-306.

\section{How to cite this article:}

Vinothini, R., and Lali Growther. 2016. Antimicrobial and Phytochemical Analysis of Methanolic and Aqueous Extract of Annona muricata (Leaf and Fruit). Int.J.Curr.Microbiol.App.Sci. 5(10): 617-625. doi: http://dx.doi.org/10.20546/ijcmas.2016.510.069 